Psychology of Language and Communication 2011, Vol. 15, No. 1

VERSITAOPEN

DOI: $10.2478 / \mathrm{v} 10057-011-0007-\mathrm{z}$

\title{
BOOK REVIEW: \\ Jenny Reeves \& Alison Fox (Eds.), \\ Practice-Based Learning: Developing Excellence in Teaching. Edinburgh: Dunedin Academic Press 2008, 87 pp.
}

Education is the process of learning and understanding, which is not restricted to school textbooks. It is a holistic process and continues through our life. Even the regular happenings and events around us educate us, in one way or another. It does not seem to me an exaggeration to say that the existence of human beings is fruitless without education. An educated person has the ability to change the world, as he/she is brimming with confidence and assured of making the right moves. The present book dwells on the significance of teachers' education from a practice-based perspective.

Practice-based Learning: Developing Excellence in Teaching, edited by Jenny Reeves and Alison Fox, contains a Series Editor Introduction and brings together the contributions of 13 teachers in 6 chapters, followed by references and an index on 87 pages. The book belongs to the series called Policy and Practice in Education edited by Jim O'Brien and Christine Ford. The contributors try to present a framework for teacher development based on ideas of collaboration and enquiry (p.1).

Each chapter draws on the experience of the contributors in a professional enquiry program in Scotland and addresses some important issues leading to the achievement of Chartered Teacher status. Going through six chapters of the book, several important themes or principles can be identified. I shall look at them from a critical standpoint.

The editors' introductory chapter focuses on teacher professionalism and school improvement. They consider teaching as a profession and give a full account of teacher professionalism in Scotland. However, some people think that if"everybody boil water and coach basketball, then they kind of feel the same way about teaching" (Wallis, 1994, p. 63). The emergence of home schooling and charter schools is partly based on the perception of teaching as a "non-profession." Even though we admit the need for professional preparation of the teacher, still some people think that the profession of teaching is fundamentally different from those that receive the greatest public recognition."Teachers are not professionals in the conventional 
sense of the term" (Prate \& Rury, 1991, p. 64). However, there is another effort to define teaching as a "new professionalism". It seems the editors have taken this latter view.

The second important point I noticed through the whole book is the emphasis on the role of experiential education, particularly the process of experiential learning which is implied in practice-based teaching. Experiential education encompasses experiential learning, or learning from both formal and informal experience. Experiential learning considers the subjective experiences of the colearners to be critical in the learning process and is largely based on principles from the educational philosophy of John Dewey. The professional experience from practice-based teaching shapes a person's frame of reference for practice and any lifelong professional learning that he or she may later undertake. Experiential learning is education that occurs as a direct participation in the events of life. The contributors are right since the philosophy of experiential learning is that people learn most effectively through direct, hands-on experience, as long as these experiences are well-designed and facilitated. Yet experience alone is insufficient unless it is supplemented with facilitated exercises that involve thinking, discussing, or creatively processing cognitions and emotions related to the experience. Thus, practice-based learning attempts to arrange particular sets of distinct encounters within courses and fieldwork to gain experiences that are related to enhancing learning. The teachers' facilitative instruction is also affected by a variety of knowledge and unique experiences. In practice-based teaching their instructional techniques undergo constant construction and reconstruction through reflection during and after the teaching engagement with the student. This reflection process has the teacher as a learner step back from each experience to carefully ponder and learn.

The third point is practice-based learning for teachers which assumes a facilitative teaching approach on the part of the teacher which is quite different from the traditional teaching role manifested in the classroom. In this role, the teachers are educators who assume a facilitative, or "coaching," function. To effectively enhance their capacities, specific and clear recommendations should be developed and disseminated among all teachers. Practice-based learning in this sense, as the contributors argue, offers collaborative, structured opportunities for the teachers as learners and derives benefits. With appropriate "coaching," or practice-based teaching from the teacher, a student integrates what he or she has learned elsewhere in the curriculum through planned experiences, in addition to refining his or her critical thinking and judgment. The adaptive nature of the facilitative partnership helps meet the changing developmental learning needs of professional practitioners.

The fourth issue worthy of attention is the teachers' critical thinking and analysis skills which give added value to their learning that goes far beyond the memorization of information related to a topic. Practice-based teaching includes 
observation, feedback, and reflective activities that promote critical thinking among teachers as learners. One popular definition posits that critical thinking is skillful, responsible thinking that facilitates good judgment because it (1) relies upon criteria, (2) is self-correcting, and (3) is sensitive to context. Another prevalent perspective emphasizes that critical thinking is synonymous with logic or the hypotheticodeductive method (proposing hypotheses and testing their acceptability or falsity by determining whether consequences are consistent with observed data), whereas a third view frames critical thinking as a process of inquiry and problem solving. Whatever the contributors assert on critical thinking, observation, reflective activities and feedback seem to be in line with the findings of different researches such as (Tripp, 1993; Smith, 1996; Bulter, 2002)

The fifth main issue discussed considers teaching as an ongoing process of lifelong learning that involves a reciprocal dynamic, which is a process of teaching and learning that requires engagement of all students and teachers, and that yields benefits for all participants. The academic partnership between teachers and students helps to inform and improve the teachers' knowledge to better meet the needs of the field and hence, to meet the needs of the learners. Practice-based teaching, as the writers note, contributes needed resources, technical assistance, and consultation to practitioners and consequently contributes a scholarship-based service to the community.

Finally, interdisciplinary teaching provides a meaningful way in which students can use knowledge learned in one context as a knowledge base in other contexts in and out of school. Multiple professional and community perspectives are often at the heart of practice-based teaching. Given the complexity of educational challenges, interdisciplinary approaches have become the norm rather than the exception in teaching practice. In addition to teachers' collaboration, the increased community representation and participation lends a multidimensional feature to practice-based teaching. As it has been aptly emphasized through the book, due to the increasingly complex economic and social forces affecting the educational system, schools should provide leadership in ecologically based, transdisciplinary partnerships with related disciplines and professional academies in areas such as medicine, business, law, and computer science, in order to strengthen modern education and practices.

Although I expected to find more practical examples and explanations on the psychological and emotional relationship between teachers and learners in the process of practice-based learning, this written edited volume is a significant contribution to the study of teachers' practice-based learning. It is a useful resource for all teachers, even experienced ones. Although many different examples are given locally within the domain of Scotland, the book has much to offer globally. This work serves teachers quite well because it provides them with a framework within which there is considerable information on both the theoretical and mostly empirical aspects of practice-based learning. 


\section{References}

Butler, J. (2002). What is critique? An essay on Foucault's virtue. Malden, MA: Blackwell.

Pratte, R. \& Rury, J.L. (1991). Teachers, professionalism, and craft. Teachers College Record, 93, 59-72.

Smith, I. (1996). Teaching for effective learning. Dundee: Scottish Consultative Committee on the Curriculum.

Tripp, D. (1993). Critical incidents in teaching: Developing professional judgment. London: Routledge.

Wallis, C. (1994). A class of their own. TIME, 31 October, 53-63. 